\title{
Improvement of Technologies for Mining Waste Management
}

\author{
Veiko Karu, Angela Notton, Julia Gulevitš, Ingo Valgma, Tiit Rahe \\ Tallinn University of Technology, Department of Mining, Estonia \\ veiko.karu@ttu.ee; angela@warren.ee; julia.gulevich@gmail.com;ingo.valgma@ttu.ee; \\ tiit.rahe@ttu.ee
}

\begin{abstract}
Mining waste reduction methods include all mining processes beginning from resource distribution until final products in the plant. For comparing and testing possibilities of mine waste reduction, a cooperation project has been set up aiming to create a transnational network with regional networks. The activities carried out on the regional and transnational level will secure better access to knowledge, state-of-the-art technologies and good practice. The study addresses all the waste management challenges and opportunities facing the Baltic Sea Region mining industry, which should be understood as extending to all forms of extraction of natural non-renewable resources.

In addition to the main mineral resource, oil shale, there are sufficient reserves of limestone and dolostone, peat, sand, gravel and clay. Phosphorite and granite are considered as occurrences in today's economic situation, in spite of the fact that phosphorite has been extracted for 70 years in the past. All previous mining activities have produced mining waste, e.g. the total volume of waste rock from Estonian oil shale mining is more than 76 million $\mathrm{m} 3$ and covers about 790 ha [31][32][33][34]. From an environmental point of view Estonia is in good position, not having acidic reactions and having neutralising alkaline limestone present in all mining areas. Thanks to this, reclamation is easily done with the help of the same mining equipment. Water is purified in settling ponds and does not require additional chemical treatment. For underground mining, the main concern is the stability of the room and pillar mining area [35][37].

Similar problems are found in Sweden and Finland. In Sweden, there are several old deposits from shale mining, the largest one (Kvarntorp) contains some 40 million $\mathrm{m} 3$ of crushed processed black shales and contains several metals of potential value.
\end{abstract}

Keywords - mining, waste management, pilot unit, Baltic Sea Region, oil shale, sand, gravel, waste heap.

\section{INTRODUCTION}

Mining waste management issues have to take consideration in all mining sites. The main aim of mining waste management is to use Best Available Technology (BAT) in production line, giving minimal waste and best products. How to use old waste heaps as raw material is also a problem. A possible solution is to test different mining waste reduction methods and choose the most practical technology for the site [9][12].

In Estonia, two types of mining waste are currently produced: waste rock from oil shale separation and limestone mining fines (grain size 0-4 $\mathrm{mm}$ ) from crushing and screening. In addition, previously deposited phosphate rock flotation sand and uranium ore processing waste are being handled. Estonia has 48 mining waste objects [11]. Some of them are limestone fines, but most are oil shale fines.

Mining waste is located and measured in amounts and substances: 1) waste rock dumps are located in huge amounts near the areas of abandoned mines; 2) mining waste contains very often metal elements, including a mix of rare earth metals; 3 ) the total amount mining and mineral processing wastes stored on the waste facilities.

The aim of this study is locate mining waste heaps and analyze mining waste reduction methods and find solutions to use mining waste as product in different mineral resources.

\section{METHODS}

Mining waste reduction methods include all mining processes beginning from resource distribution until final yield in the plant. For comparing and testing possibilities of mine waste reduction the study addresses all the waste management challenges and opportunities facing the Baltic Sea Region (BSR) mining industry, which should be understood as extending to all forms of extraction of natural non-renewable resources.

The majority of all excavated materials are used in civil, industrial and road building, renewing of road network and railways alone needs many million cubic meters of building stone, gravel, sand and other materials [30].

The Estonian Road Administration put into practice in the spring 2012 the directive regulating mineral resources used in the determination of roadworks. This directive restricts greatly the amount of suitable mineral resources, because filtration coefficient requirements not being fulfilled. In case the quality of a natural resource does not meet the requirements, one option is to use a variety of enrichment to improve the quality. Many quarries, where mining permit is issued, intended for use in road construction, drop out of the competition, because the natural quality and the processed quality are not as required. 
To answer the question why there is a lot of waste production in limestone and dolostone reserves, it is important to know about limestone and dolostone production methods, its standard and specifications. In order to better understand the current situation as a whole, it is necessary to describe the existing standards, which are used by the Estonian Road Administration for technical requirements and specifications definition in road construction projects. According to the decree of the head of the Estonian Road Administration no. 95 17.04.2006 "The requirement for acceptance of construction and repair of public roads" construction material for road pavement must meet strict requirements, which are listed below in Table 1[2].

As it can be seen in Table 1, the fine particle content for limestone aggregates is $2 \%$, which increases waste content in production line up to $40 \%$. It is quite necessary to get the crusher alignment installed and optimized for given characteristics of the deposit. For instance, many manufactures work according to the following processing system: first there is a jaw crusher complex, secondly a crusher is processing the overall fractions, which are forwarded from the screen. To achieve the highest quality of aggregate, the material should be lead to an additional cone crusher. It helps to reduce the weak grain content, but the number of the waste material rises up to $40 \%$ [3]. Consequently, higher quality rank for limestone and dolostone aggregates means larger waste content in production line.

TABLE I

THE AGGREGATES QUALITY SPECIFICATIONS [1]

\begin{tabular}{|l|l|l|l|l|l|}
\hline Sample & Class I & Class II & Class III & Class IV & Norms \\
\hline $\begin{array}{l}\text { Abrasive resistance upon the } \\
\text { Nordic test }\end{array}$ & $\leq 10$ & $\leq 14$ & PN & PN & EVS-EN 1097-9 \\
\hline $\begin{array}{l}\text { Frost-resistance } \\
\text {-upon direct freezing }\end{array}$ & $\leq 2$ & $\leq 2$ & $\leq 4$ & $\leq 4$ & EVS-EN 1367-2 \\
\hline $\begin{array}{l}\text { Crushing strength upon the } \\
\text { Los Angeles test }\end{array}$ & $\leq 20$ & $\leq 20$ & $\leq 30$ & $\leq 35$ & EVS-EN 1097-2 \\
\hline Fine particle content & $\leq 1$ & $\leq 1 / \leq 2$ & $\leq 2 / \leq 3$ & $\leq 3 / \leq 4$ & EVS-EN 933-1 \\
\hline $\begin{array}{l}\text { Grain shape by the plateness } \\
\text { factor }\end{array}$ & $\leq 10$ & $\leq 20$ & $\leq 25$ & $\leq 35$ & EVS-EN 933-3 \\
\hline $\begin{array}{l}\text { Radioactivity } \\
\text { nation }\end{array}$ & & $\begin{array}{l}\text { shows that generate } \\
\text { natural radioactivity } \\
\text { not more than } 85 \text { Bq / }\end{array}$ & $\begin{array}{l}\text { Estonian } \\
\text { Ladiation }\end{array}$ & $\begin{array}{l}\text { EVS EN 1744-1 } \\
\text { p.15.1 }\end{array}$ & \\
\hline
\end{tabular}

A. Production of material from mining waste appropriate for construction industries (aggregate for structural concrete).

Therefore, construction of a mobile unit for sieving, crushing and screening of material has been chosen. The mobile unit can be transported to different locations of waste dumps. Alternatives to Portland cement and other standard aggregates are being sought.

Mining related waste is mainly solid waste from separation and processing, operating solid waste from overburden removal and drifting, liquid waste from dewatering, processing and washing processes. Origin of mining waste is separation waste form heavy media separation (HMS), processing waste, crushing and screening waste [14] [16] [36].

The main usage of solid mining waste is material for filling, construction and cementing [35]. The principal direction of developing mining technology is filling the mined area [23][24]. This provides control over majority of environmental effects. Filling the workings decreases the loss of resources and land subsidence, and at the same time provides usage for stockpiling. Filling the spoils of a surface mine decreases dewatering; harmless waste can be used for filling surface mines and in this manner offer new building ground [22] [25][26] [27] [28][34] [38].
B. A pilot plant to develop business opportunities for SMEs by extracting valuable and/or hazardous metals etc. from mining and metal processing waste.

The pilot unit includes: (1) Crushing and milling (2) Leaching (3) Recovery of elements from solution. There is a possible innovation related to treating old tailings and slags through leaching with different aqueous media, which has not been performed before. Transnational relevance as metal recovery from waste is not usual in BSR.

The objective is to test recycling of mine waste with a view to future commercial potential [14]. A mobile module will be constructed, transportable to sites where waste is processed. The main element is dry grinding and classification of the material according to the grain size. Simultaneous analysis is required to control the promotion of classification procedure. A novelty is that produced material combined with other components can be used as an adsorbent in waste water purification [12].

An investment objective is to prepare aggregate for waste from mineral treatment plant and useful minerals enrichment plant. Aggregate from finegrained waste will be produced using an agglomeration process. Installation will include screamer, crusher, mixer, and measurement devices 
(to control physical and chemical properties). The installation will allow to test various types of coal processing waste, and other mineral processing waste (sandstone/mudstone/claystone mixed waste from gravity washers in heavy liquids). The product will be crushed aggregates mix 4(5)-31.5 mm, useful in mining, building and road construction.

\section{RESULTS}

In total, 48 different waste heaps or production loss heaps have been defined in Estonia (Fig. 1, Fig. 2) [11]. For each heap, many characteristics are defined to describe its situation. The main characteristics are: heap location, time period of mining, mined mineral resources, type of heap, geometry of heap (height, area, volume), administrator, description of material, category of waste heap according to the directive.

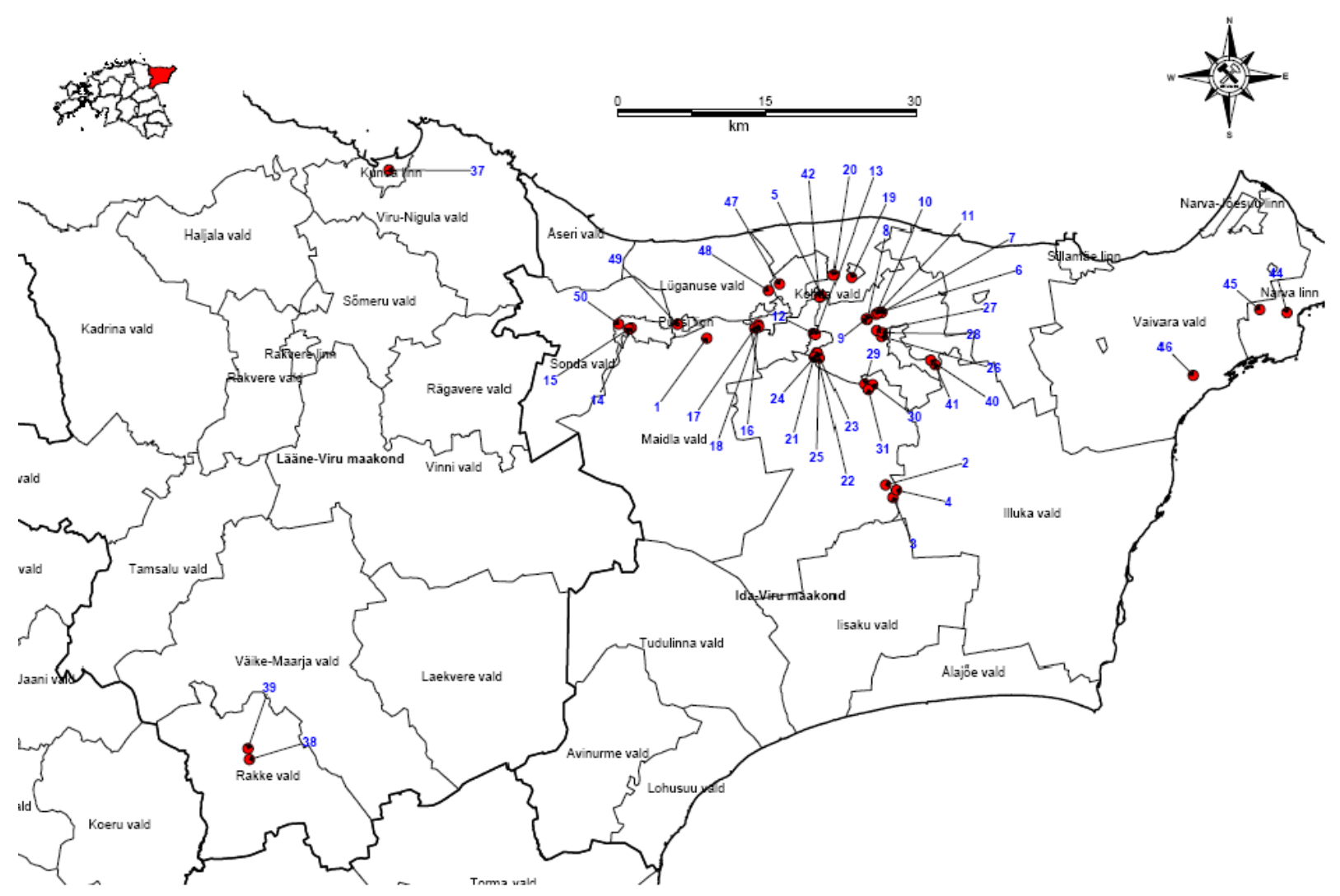

Fig. 1 Mining waste objects - East Estonia

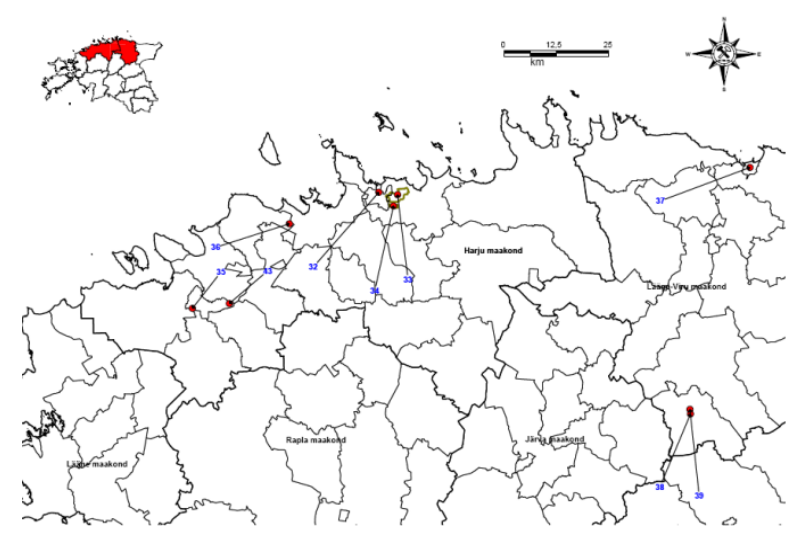

Fig. 2 Mining waste objects - North Estonia

Oil shale utilisation losses reach $70 \%$ in some cases [21][29][39]. These are closely related to legislation, backfilling and waste rock usage [30][31]. Much smaller sections include production of oil, electricity and chemicals which are the focus of most of research and development today. Current urgent topics for investigating, testing and developing of oil shale mining are backfilling, mechanical extracting of shale, fine separation, selective separation and optimised drilling and blasting [4][5][6][7][8][10][13][15].

First small scale tests with dry crushing have been carried out at several sites with oil shale, run of mine (Fig. 3) and waste rock in addition to sand and gravel crushing [12]. The material has been evaluated and initial results received. 


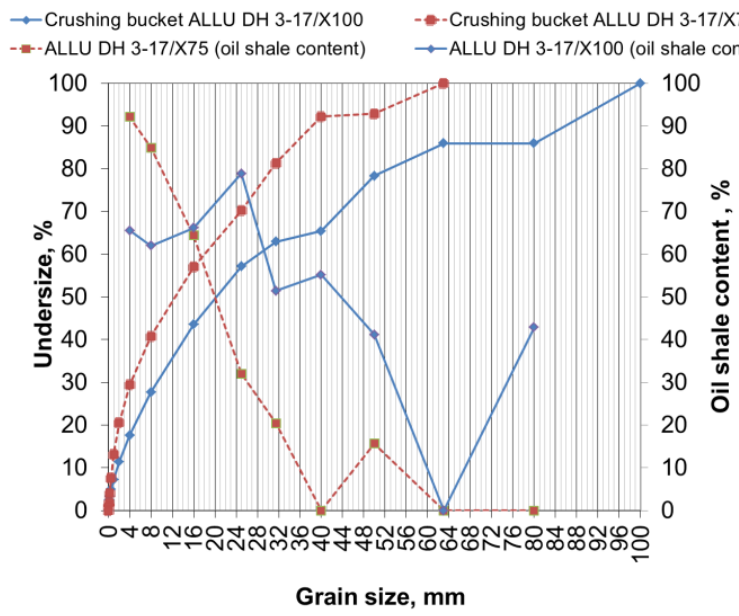

Fig. 3 Oil shale selective crushing test results with ALLU crushing buckets

\section{Discussion}

To avoid open quarries, where the material not suitable for using in building, we must know the quality at particular locations. The compositions of sand and gravel deposits in the Harju County have been analysed. Thus it is possible to determine precisely enough usability exploration, as well as areas where it is possible to find new gravel, sand or complex deposits.

All 27 presently operating gravel and sand pits may be divided to groups considering their position to glaciation stadial, distance from ice margin and genesis. In the central part of the county, between the Pandivere and Palivere Stadial zones, glacial sediment forms four groups of deposits oriented in the direction of ice margin, $\mathrm{NE} 45-75^{\circ}$, during the deglaciation here [17][18] [19][20].

Sediments near the Pandivere Stadial ice margin contain more gravel and clay than fluvioglacial sandy deposits. These positions are Voose (Kuressaare) and Punamäe deposits (Fig. 5). Next deposits is characterized by variation of gravel part $20-45 \%$ and decreasing of clay content up to $3-6 \%$ in the Vahelaane and Kose-Risti open pits. In the Vahelaane open pit it was possible to observe, how older bedded fluvioglacial sands are deformed into folds, their upper part subsequently eroded and covered by new layers of gravel and sand (Fig. 4).

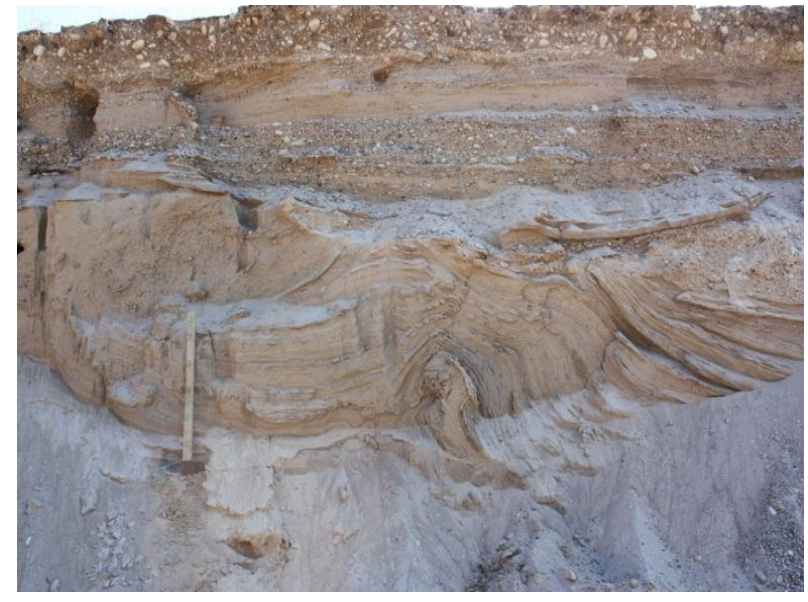

Fig. 4 Folded sand in the lower part is deformed into folds, the later part of the sequence is eroded and covered by horizontal gravel and sand layers. The Vahelaane open pit.

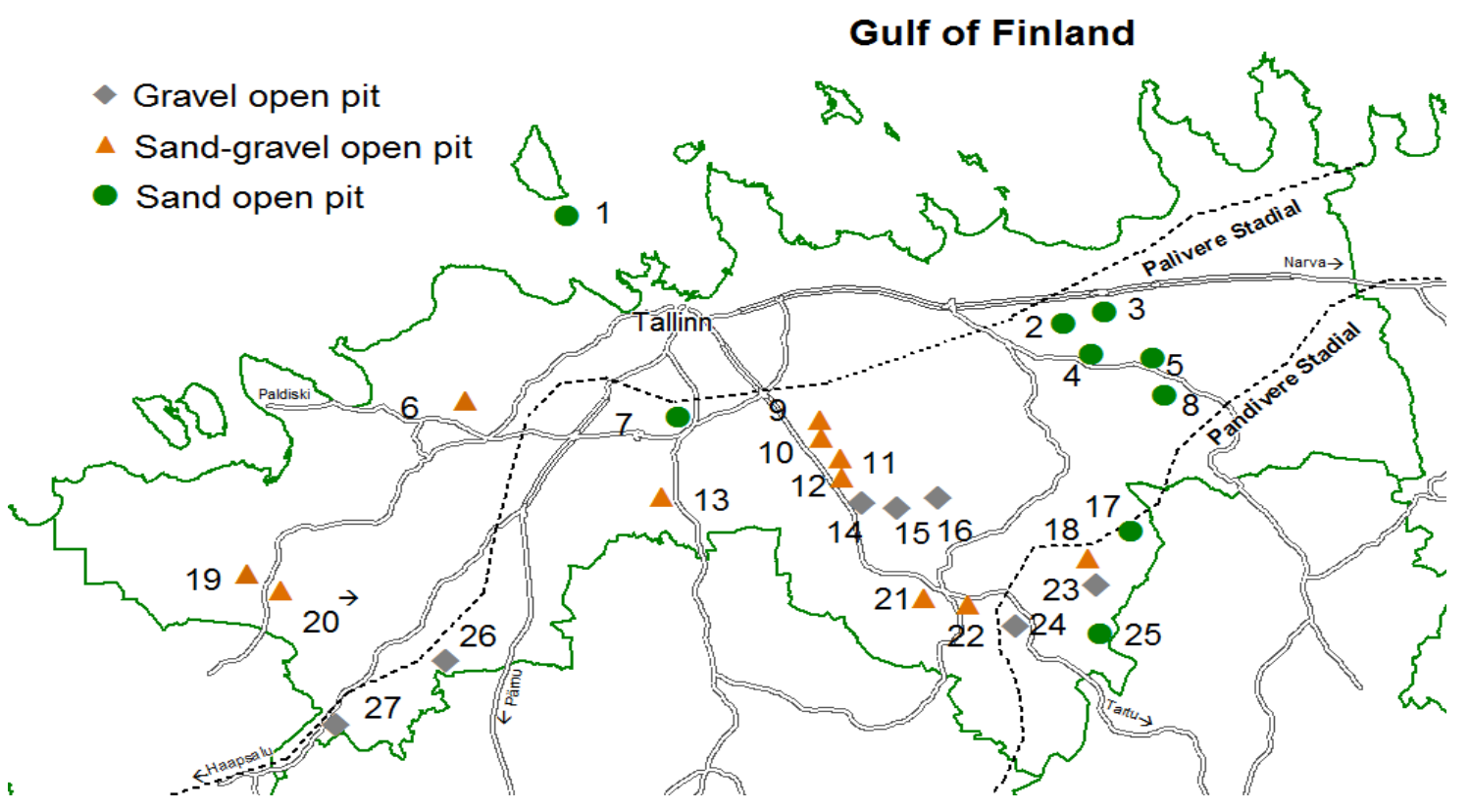

Fig. 5 Working gravel, sand-gravel and sand open pits of the Harjumaa County in 2013.

1- Naissaare, 2-Huntaugu, 3-Kuusalu, 4- Soodla, 5- Raudoja, 6- Karjaküla, 7- Tallinn-Saku, 8- Poolvahe, 9- Seli, 10Suuresöödi, 11- Suuresta, 12- Vaidasoo, 13- Kõrnumäe, 14- Piuga, 15- Nõmme, 16- Pihuvere, 17- Vetla, 18- Vahelaane, 19Tatramäe, 20- Audevälja, 21- Kose-Risti, 22- Sõmeru, 23- Voose(Kurissaare), 24- Punamäe, 25-Kiruvere, 26- Mustu, 27 - Kalda. 


\section{Karu V., Notton A., Gulevitš J., Valgma I., Rahe T. IMPROVEMENT OF TECHNOLOGIES FOR MINING WASTE MANAGEMENT}

\section{SUMMARY}

Mining waste management issues have to take consideration in all mining sites. The main aim of mining waste management is to use Best Available Technology (BAT) in production line, giving minimal waste and best products. It is also a problem how to use old waste heaps as raw material. A possible solution is to test different mining waste reduction methods and choose the most practical technology for the site.

Mining waste reduction methods include all mining processes beginning from resource distribution until final products in the plant. For comparing and testing possibilities of mine waste reduction the study addresses all the waste management challenges and opportunities facing the Baltic Sea Region mining industry, which should be understood as extending to all forms of extraction of natural non-renewable resources.

To answer the question why there is a large amount of waste production in mining limestone and dolostone reserves it is important to know about limestone and dolostone production methods, its standards and specifications. In order to better understand the current situation as a whole, it is necessary to describe the existing standards used by the Estonian Road Administration for technical requirements and specifications definition in road construction projects.

To avoid opening quarries, where material is not suitable for building, we must have overall knowledge on quality at each location.

Futures research will focus on using environmental friendly mining methods in all areas of mineral resource mining. For better mining waste management different pilot units have been designed in order to determine how to use old waste heaps as new raw material.

\section{ACKNOWLEDGMENT}

This study is related to the project MIN-NOVATION http://www.min-novation.eu; ETF8123 "Backfilling and waste management in Estonian oil shale industry" http://mi.ttu.ee/ETF8123; Energy Technology Program Sustainable and environmentally acceptable oil shale mining No. 3.2.0501.11-0025 - mi.ttu.ee/etp and Doctoral School of Energy and Geotechnology II, interdisciplinary research group "Sustainable mining" DAR8130/1.2.0401.09-0082 - mi.ttu.ee/doktorikool.

\section{REFERENCES}

[1] Asphalt Specifications AL ST 1-07, Tallinn 2007 Estonian Asphalt Pavement Association B.I.;

[2] Gulevich, J. (2010). Sustainable development and methods of quality assessment in the road construction aggregates production, Tallinn

[3] Gulevich, J., Bashkite, V., Isküll, R. (2010). Sustainable development of Estonian mineral resources for economical usage in roads construction, Tallinn

[4] Karu, V. (2009). Modelling oil shale mining space and processes. In: Book of abstracts: International Oil Shale Symposium, Tallinn, Estonia, 8-11 June 2009: Tallinn:, 2009, 96.
[5] Karu, V. (2009). Modelling oil shale mining space and processes. Valgma, I. (Toim.). Resource Reproducing, Low-wasted and Environmentally Protecting Technologies of Development of the Earth Interior (1 pp.). Tallinn: Department of Mining TUT; Russian University of People Friendship

[6] Karu, V. (2009). Spatial planning on under mined areas. Valgma, I. (Toim.). Resource Reproducing, Low-wasted and Environmentally Protecting Technologies of Development of the Earth Interior (3 pp.). Tallinn: Department of Mining TUT; Russian University of People Friendship

[7] Karu, V. (2010). Mining engineering models for Estonian ol shale industry : [BAUMA 2010 ,The Peak of Excellence“]. Valgma, Ingo (Toim.). Mäendusuuringud ja kaevandamine. (1). Tallinn: TTÜ mäeinstituut

[8] Karu, V. (2010). Spatial modelling tools in mining areas for improving mining process. Lahtmets, R. (Toim.). 8th International Symposium "Topical problems in the field of electrical and power engineering. Doctoral school of energy and geotechnology". II : Pärnu, Estonia, 11.01.-16.01.2010 (129 133). Tallinn: Elektriajam

[9] Karu, V. (2011). European Union Baltic Sea region project "MIN-NOVATION". Oil Shale, 28(3), 464 - 465.

[10] Karu, V. (2012). Potential Usage of Underground Mined Areas in Estonian Oil Shale Deposit. (Doktoritöö, Tallinna Tehnikaülikool, Energeetikateaduskond, Mäeinstituut) Tallinn University of Technology Press

[11] Karu, V.; Leiaru, M.; Valgma, I. (2012). Kaevandamisjääkide andmebaas. Valgma, I.; Väizene, V.; Kolats, M.; Karu, V. (Toim.). Kaevandamine ja keskkond $(57-62)$. Tallinn: Tallinna Tehnikaülikooli mäeinstituut

[12] Karu, V.; Valgma, I.; Rahe, T. (2013). Mining Waste Reduction Methods. Zakis, J. (Toim.). 13th International Symposium "Topical Problems in the Field of Electrical and Power Engineering", Doctoral Scholl of Energy and Geotechnology II, Pärnu, Estonia, 14-19.01.2013 (278 - 280). Tallinn: Elektrijam

[13] Karu, V.; Valgma, V.; Västrik, A. (2007). Multi criterial modelling of oil shale mining fields. Mining and the Environment 2007 (225). Baia Mare: Freiberg TU

[14] Karu, V.; Västrik, A.; Anepaio, A.; Väizene, V.; Adamson, A.; Valgma, I. (2008). Future of oil shale mining technology in Estonia. Oil Shale, 25(2S), 125 - 134.

[15] Karu, V.; Västrik, A.; Valgma, I. (2008). Application of modelling tools in Estonian oil shale mining area. Oil Shale, 25(2S), $134-144$.

[16] Koitmets, K.; Reinsalu, E.; Valgma, I (2003). Precision of oil shale energy rating and oil shale resources. Oil Shale, 20(1), 15 24.

[17] Notton, A. (2010). The genetic systematization of the sandy deposits using their granulometric and mineral composition in Harjumaa County, Estonia. Lahtmets, R. (Toim.). 8th International Symposium "Topical problems in the field of electrical and power engineering. Doctoral school of energy and geotechnology". II : Pärnu, Estonia, 11.01.-16.01.2010 (300 305). Tallinn: Elektriajam

[18] Notton, A.; Sõstra, Ü. (2013). Quaternary and Paleozoic Mineral Resourees of the Harjumaa County, Estonia. Zakis, J. (Toim.). 13th International Symposium "Topical Problems in the Field of Electrical and Power Engineering", Doctoral Scholl of Energy and Geotechnology II, Pärnu, Estonia, 14-19.01.2013 (265 269). Tallinn: Elektrijam

[19] Raukas, A. (1992).’'Ice-marginal formations of the Palivere zone in the astern Baltic", Sveriges geol. unders., Ser.Ca 81, 1992, pp.277-284.

[20] Raukas, A., Rähni, E., Miidel, A. (1971). Marginal glacial formations in North Estonia. Tallinn, Valgus (In Russian, with summary in Estonian and English).

[21] Reinsalu, E.; Valgma, I. (2007). Oil Shale Resources for Oil Production. Oil Shale, 24, 9 - 14.

[22] Sabanov, S.; Reinsalu, E.; Valgma, I.; Karu, V. (2009). Mines Production Quality Control in Baltic Oil Shale Deposits. Valgma, I. (Toim.). Resource Reproducing, Low-wasted and Environmentally Protecting Technologies of Development of the Earth Interior (1 pp.). Tallinn: Department of Mining TUT; Russian University of People Friendship 
[23] Sabanov, S; Karu, V; Reinsalu, E; Valgma, I (2009). Production quality control in mines of Baltic oil shale deposits. Tallinn Technical University, 2009.

[24] Tammeoja, T.; Loko, M.; Valgma, I.; Karu, V.; Tohver, T. (2007). Oil shale reserves in Estonia. In: 4th International Symposium "Topical Problems in the Field of Electrical and Power Engineering" : Doctoral School of Energy and Geotechnology: 4th International Symposium "Topical Problems in the Field of Electrical and Power Engineering", Kuressaare, Estonia, 15.-.20.01.2007. (Toim.) Lahtmets, R.. Tallinn: Tallinn University of Technology Faculty of Power Engineering, 2007, $94-95$.

[25] Valgma, I (2000). Post-stripping processes and the landscape of mined areas in Estonian oil shale open casts. Oil Shale, 17(2), $201-212$.

[26] Valgma, I (2003). Estonian oil shale resources calculated by GIS method. Oil Shale, 20(3), 404 - 411.

[27] Valgma, I. (2002). Geographical Information System for Oil Shale Mining - MGIS. (Doktoritöö, Tallinna Tehnikaülikool) Tallinn: Tallinn Technical University Press

[28] Valgma, I. (2009). Dependence of the mining advance rate on the mining technologies and their usage criteria. Valgma, I. (Toim.). Resource Reproducing, Low-wasted and Environmentally Protecting Technologies of Development of the Earth Interior (2 pp.). Tallinn: Department of Mining TUT; Russian University of People Friendship

[29] Valgma, I. (2009). Oil Shale mining-related research in Estonia. Oil Shale, 26(4), 445 - 150.

[30] Valgma, I.; Karu, V. (2006). Mining in Estonia - a Development Towards the EU. In: EU Legislation as it Affects Mining : Proceedengs of TAIEX Workshop in Tallinn: INFRA 22944 TAIEX Workshop, Tallinn, 30.11.-02.12.2006. (Toim.) Valgma, I.; Buhrow, Chr.. Tallinn: Tallinna Tehnikaülikool, 2006, 98 102.

[31] Valgma, I.; Karu, V.; Anapaio, A.; Väizene, V. (2007). Increasing oil shale quality for meeting EU environmental requirements. Mining and the Environment 2007 (195 - 205). Baia Mare: Freiberg TU

[32] Valgma, I.; Karu, V.; Västrik, A.; Väizene, V. (2007). Future of oil shale mining. In: Georesources and public policy: research, management, environment : abstracts: 15th Meeting of the
Association of European Geological Societies, Tallinn (Estonia), 16-20 September 2007. (Toim.) Hints, O.; Kaljo, S.. Tallinn: Eesti Geoloogia Selts, 2007, 81.

[33] Valgma, I.; Karu, V.; Viil, A.; Lohk, M. (2007). Oil shale mining developments in Estonia as the bases for sustainable power industry. In: 4th International Symposium "Topical Problems in the Field of Electrical and Power Engineering" : Doctoral School of Energy and Geotechnology: 4th International Symposium "Topical Problems in the Field of Electrical and Power Engineering", Kuressaare, Estonia, 15.-.20.01.2007. (Toim.) Lahtmets, R.. Tallinn: Tallinn University of Technology, Faculty of Power Engineering, 2007, 96 - 103.

[34] Valgma, I.; Kattel, T. (2005). Low depth mining in Estonian oil shale deposit-Abbau von Ölschiefer in Estland. In: Kolloquium Schacht, Strecke und Tunnel 2005 : 14. und 15. April 2005, Freiberg/Sachsen: Kolloquium Schacht, Strecke und Tunnel 2005 : 14. und 15. April 2005, Freiberg/Sachsen. Freiberg: TU Bergakademie, 2005, 213 - 223.

[35] Valgma, I.; Leiaru, M.; Karu, V.; Iskül, R. (2012). Sustainable mining conditions in Estonia. 11th International Symposium "Topical Problems in the Field of Electrical and Power Engineering", Doctoral Scholl of Energy and Geotechnology, Pärnu, Estonia, 16-21.01.2012 (229 - 238). Tallinn: Elektriajam

[36] Valgma, I.; Reinsalu, E.; Sabanov, S.; Karu, V. (2010). Quality control of Oil Shale production in Estonian mines. Oil Shale, 27(3), 239 - 249.

[37] Valgma, I.; Tammeoja, T.; Anepaio, A.; Karu, V.; Västrik, A. (2008). Underground mining challenges for Estonian oil shale deposit. Buhrow, Chr.; Zuchowski, J.; Haack, A. (Toim.). Schacht, Strecke und Tunnel $(161-172)$. Freiberg : TU Bergakademie

[38] Valgma, I.; Västrik, A.; Kõpp, V. (2010). Sustainable mining technologies for Estonian minerals industry. Lahtmets, $\mathrm{R}$ (Toim.). 9th International Symposium Pärnu 2010 "Topical Problems in the Field of Electrical and Power Engineering" and "Doctoral School of Energy and Geotechnology II", Pärnu, Estonia, June 14 - 19, 2010 (69 - 73). Tallinn: Estonian Society of Moritz Hermann Jacobi

[39] Väli, E.; Valgma, I.; Reinsalu, E. (2008). Usage of Estonian oil shale. Oil Shale, 25(2S), $101-114$. 